\title{
Is India heading towards a new high? : An optimistic approach to estimate ending life-cycle and cumulative cases by the end of the major COVID-19 pandemic wave in India and some of its states.
}

\author{
Dr. P. Gupta ${ }^{1}$, Prof. K. K. Sharma ${ }^{2}$, Prof. S.D. Joshi ${ }^{3}$ and Dr. S. Goyal \\ ${ }^{1}$ Department of Electronics Engineering, Government Polytechnic College, Jaipur, India \\ ${ }^{2}$ Department of Electronics and Communication Engineering, Malviya National Institute of \\ Technology, Jaipur, India \\ ${ }^{3}$ Department of Electrical Engineering, Indian Institute of Technology, New Delhi, India \\ ${ }^{4}$ Department of Medical \& Health, Government of Rajasthan, Jaipur, India \\ ${ }^{1}$ E-mail: praveenguptamnit@gmail.com
}

\begin{abstract}
Projecting the COVID-19 curve parameters such as ending-lifecycle and cumulative cases are helpful in guiding the policy makers to mitigate the outbreak. However, overestimating these parameters may put the public and policy makers in a muddle. In this paper, an optimistic scenario is simulated, wherein the dynamics of the COVID-19 curve is allowed to spread to such an extent that the projections of the COVID-19 parameters do not take excessively high values. Based on this scenario, the ending life-cycle and cumulative cases for India and some of its states, are predicted. Our study, suggests that the fall of the peak amplitude $(95 \%)$ of the major COVID-19 wave in India may take place by the $8^{\text {th }}$ of September 2020 with a total count of 655000 cases. Simulation results, also indicate that Maharashtra, Tamil Nadu, Delhi, Gujarat, Uttar Pradesh, Bihar, Madhya Pradesh, and Rajasthan may end up with 263700, 18140, 50600, 21130, 24420, 44170, 27080, and 28200 cumulative cases respectively.
\end{abstract}

1. Introduction: The Chinese city, Wuhan first turned into an epicentre of disease due to a severe acute respiratory syndrome coronavirus 2 (SARS-CoV-2), in December 2019 [1-3]. The situation started becoming grim around the world when travellers started roaming from China to the rest of the countries. World health organization declared the Coronavirus-19 disease (COVID-19) as a pandemic on $11^{\text {th }}$ March 2020 [4]. In the absence of a vaccine and specific treatment, most of the countries adopted the social distancing norm as one of the major policy interventions to mitigate the COVID-19 outbreak. However, estimating the COVID-19 dynamics and parameters such as cumulative cases, deaths, flattening of the curve, and ending life-cycle, at regular intervals are also vital for shaping these mitigation strategies in the right direction. Some of the taskforces rapidly disseminated information regarding these parameters to make public and governments aware regarding important facts about this disease [4-6]

Susceptible-Infected-Recovered (SIR) and its variants are established and the most common models to estimate the epidemiological disease dynamics [7-10]. Recently, many researchers tried these methods to estimate the disease dynamics of COVID-19 [1, 11-18]. However, the main disadvantage of SIR based methods is that they require estimates of critical 
medRxiv preprint doi: https://doi.org/10.1101/2020.05.30.20117440; this version posted June 4, 2020. The copyright holder for this preprint

(which was not certified by peer review) is the author/funder, who has granted medRxiv a license to display the preprint in perpetuity. It is made available under a CC-BY-NC-ND 4.0 International license .

epidemiological parameters [19]. We developed a novel method to detect flattening and estimating the ending life-cycle of COVID-19 curves using only the time-series of New Cases Per Day (NCPD) which doesn't require critical epidemiological parameters [20].

In this paper, an estimate using an optimistic scenario, based on the method [20], for the ending life-cycle and cumulative cases by the end of the major COVID-19 pandemic wave in India and some of its states is presented. An ideal scenario is also simulated, to provide hope and an opportunity to contain the COVID-19 outbreak at its earliest through appropriate policy interventions.

2. Methods: We used the method developed and reported in [20] to estimate the ending-life cycle and cumulative cases by the end of the major COVID-19 curve of India and some of its states. This method is explained briefly to maintain continuity. First, a time-series of New Cases Per Day (NCPD) is formed. The gross behaviour of the NCPD time-series is then fitted to a Gaussian function represented by the following equation:

$$
y(t)=a e^{-\left\{\left(\frac{t-b}{c}\right)\right\}^{2}}
$$

here, $t$ is the time in days, and $y(t)$ is the estimate of the gross behaviour of the NCPD timeseries. We are considering only positive values of $t$. Coefficients $a, b$ and $c$ represent the amplitude of the peak, centroid (location), and width of the curve respectively. Coefficients of this equation are obtained as per the method [20] and then the estimation of the peak amplitude is made and the relative position of the peak is also obtained. A positive value of the relative peak position indicates, how far the peak is from the current day, while the negative value indicates that peak has already arrived. In this manner, using eqn.(1), ending life-cycle of the curve is also estimated. Here, ending life-cycle means the day when the curve will come to an end.

3. Data, simulation results, and discussion: We simulated, the NCPD time-series for India and some of the states contributing most of the NCPD of India on $22^{\text {nd }}$ May 2020, as tabulated in Table-1. We used data from [21], wherein the data is fetched from the website of the Ministry of Health \& Family Welfare(MoHFW). All simulations consider the first day as the day when the relevant data was first reported on the website [21] i.e. $11^{\text {th }}$ March 2020. We divided our simulation results into the following scenarios as explained below:

Optimistic Scenario: This type of scenario is utilised when there is a consistent increase in NCPD with high values and thus leads to a situation, where projections of the COVID-19 curve parameters such as cumulative cases and ending life-cycle become too high. However, there is always a possibility that future data points may fall in values due to strict containment 
medRxiv preprint doi: https://doi.org/10.1101/2020.05.30.20117440; this version posted June 4, 2020. The copyright holder for this preprint

measures are taken in the recent past. To account for this fact, we allow dynamics of the COVID-19 curve to spread to the extent such that the estimates of these parameters do not take excessively high values in a relatively short span of time. In this situation, If we find that the relative position of the peak is having a positive value greater than 30 days, then we obtain modified coefficients $a, b$, and $c$ such that the value of the relative position of the peak becomes equal to positive 30 days or nearest to it. Here, it is also important to note that very high values of such parameters should also be taken care of by the policy makers, if consistent with future data points.

Ideal Scenario: This scenario, assumes that the NCPD will start decreasing within a few days and thus generate an estimate of the COVID-19 parameters in an ideal situation. This scenario allows policy makers to further tighten their containment measures. They can also get the idea regarding future estimates of these parameters and get motivated if data points fall according to the ideal scenario. Therefore, in the event when the relative position of the peak is having a positive value greater than 30 days, we obtain modified coefficients $a$, $b$, and $c$ such that the value of the relative position of the peak becomes equal to positive

one day or a value nearest to it. However, if we find that the relative position of the peak is having a negative value then we don't obtain modified coefficients. After obtaining the modified or original coefficients, eqn. (1) is used to calculate cumulative cases and ending life-cycle using the COVID-19 curve. Here, we calculate ending dates when the estimated peak amplitude falls to value by $90 \%$ and 95 respectively. Table- 1 shows the coefficients $a, b$, and $c$ using optimistic or actual scenario and the NCPD values for India and some of its states.

India: 5871 new cases per day were reported in India on the $22^{\text {nd }}$ of May 2020. Figure 1(a) shows two estimates, one with higher projections of NCPD and another one with an optimistic scenario. With higher projections, the relative peak position is positive 44 days, while using the optimistic scenario, the relative position of the peak is positive 30 days. This can be seen in Fig.1 (a) where current position (in green color) is at the $73^{\text {rd }}$ day $\left(22^{\text {nd }}\right.$ May 2020) while the peak position (in red color) is at the $113^{\text {th }}$ and the $103^{\text {rd }}$ day for highly projected values of NCPD and optimistic scenario respectively. Estimate using higher projections of the NCPD indicates that the cumulative cases at the end of COVID-19 life-cycle may rise to 1056000 cases with ending dates for $90 \%$ and $95 \%$ of fall in the peak amplitude by the $21^{\text {st }}$ of September (1175 cases per day) and $30^{\text {th }}$ of September (587 cases per day) respectively. However, using the optimistic scenario, we obtain 655000 cumulative cases with ending dates for $90 \%$ and $95 \%$ of fall in the peak amplitude by the $29^{\text {th }}$ of August ( 818 cases per day) and 
medRxiv preprint doi: https://doi.org/10.1101/2020.05.30.20117440; this version posted June 4, 2020. The copyright holder for this preprint (which was not certified by peer review) is the author/funder, who has granted medRxiv a license to display the preprint in perpetuity.

It is made available under a CC-BY-NC-ND 4.0 International license .

$8^{\text {th }}$ of September (409 cases per day) respectively. Figure 1(b) shows the ideal scenario. To simulate this scenario, we assumed some low values of NCPD just after the $73^{\text {rd }}$ day. Such an estimate results in 267200 cumulative cases with ending dates for $90 \%$ and $95 \%$ of fall in the peak amplitude by the $15^{\text {th }}$ of July 2020 (474 cases per day) and $21^{\text {st }}$ of July 2020 (237 cases per day) respectively. The ideal scenario indicates that India may report 237 cases per day by the end of the third week of July 2020 provided appropriate and strict policy interventions are made.

Table 1: Coefficients $a, b$, and $c$ for India and some of its states on $22^{\text {nd }}$ May 2020 using an optimistic scenario

\begin{tabular}{|l|c|c|c|c|}
\hline Country/State & NCPD & $\boldsymbol{a}$ & $\boldsymbol{b}$ & $\boldsymbol{c}$ \\
\hline India & 5871 & 8188.9 & 102.9 & 45.2 \\
\hline Maharashtra & 2345 & 3623.6 & 102.7 & 41.1 \\
\hline Tamil Nadu & 776 & 763.55 & 74.85 & 21.69 \\
\hline Delhi & 571 & 662.93 & 95.82 & 43.09 \\
\hline Gujarat & 368 & 495.27 & 75.18 & 32.73 \\
\hline Uttar Pradesh & 340 & 251.30 & 102.97 & 55.06 \\
\hline Bihar & 308 & 1111.11 & 102.8 & 22.4 \\
\hline Madhya Pradesh & 246 & 274.89 & 103.31 & 55.82 \\
\hline Rajasthan & 212 & 294.61 & 102.63 & 54.21 \\
\hline
\end{tabular}

(a)

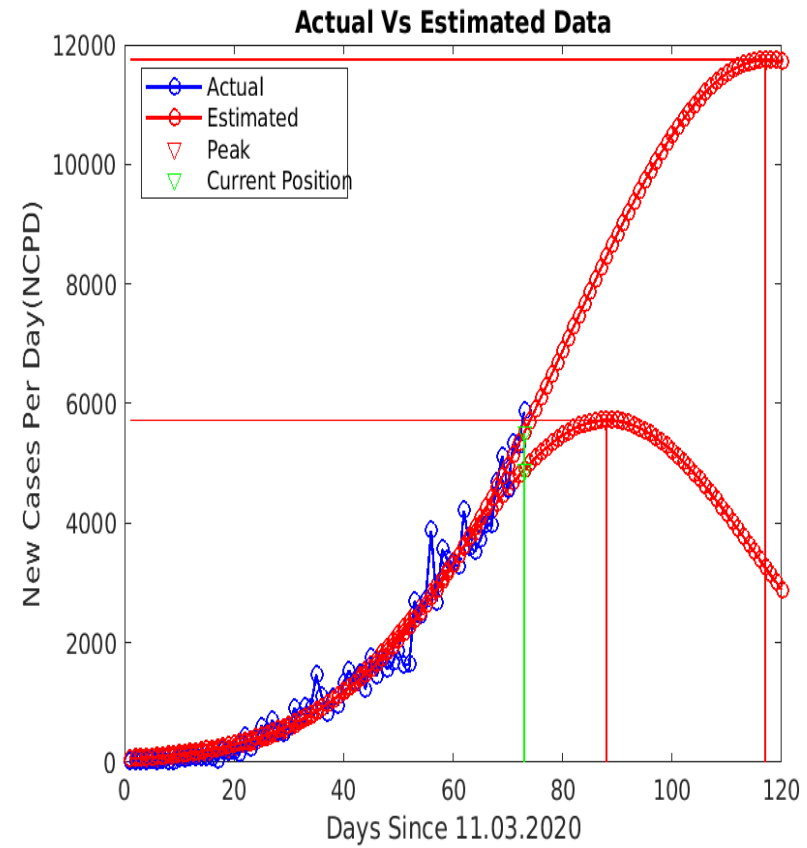

(b)

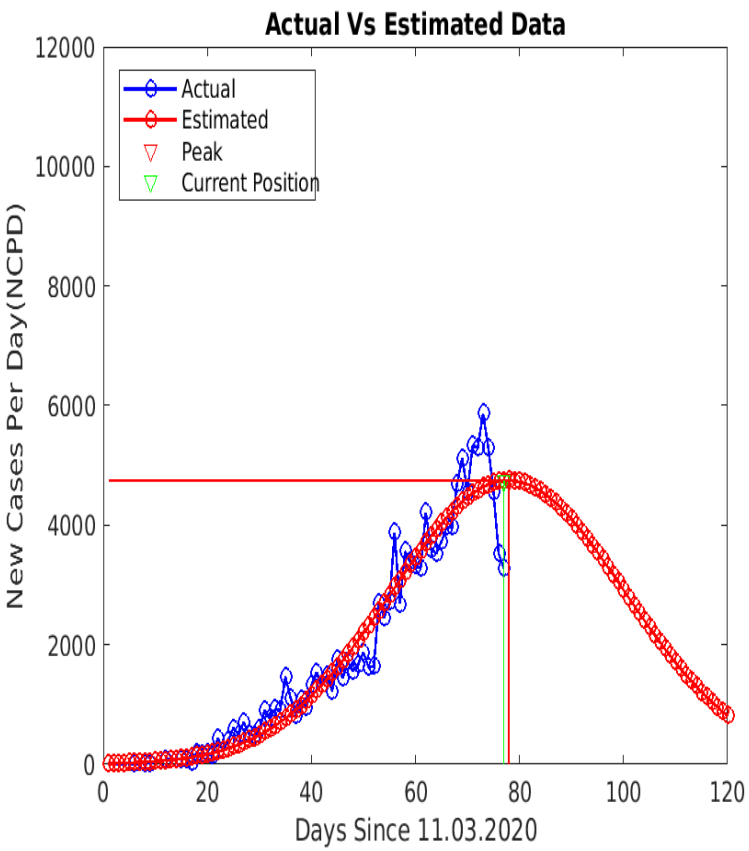

Figure. 1(a) Two estimates for India, one with higher projections of NCPD (upper-red) and another one with an optimistic scenario (lower-red), note that the position of the peak (vertical red line) with the higher projections is +44 days from the current position (vertical green line) while with optimistic scenario position of the peak is +30 days. (b) projections of NCPD with an ideal scenario 
medRxiv preprint doi: https://doi.org/10.1101/2020.05.30.20117440; this version posted June 4, 2020. The copyright holder for this preprint (which was not certified by peer review) is the author/funder, who has granted medRxiv a license to display the preprint in perpetuity. It is made available under a CC-BY-NC-ND 4.0 International license .

Maharashtra: 2345 new cases were reported in Maharashtra on the $22^{\text {nd }}$ of May 2020. Maharashtra contributed almost $40 \%$ new cases per day for India on this day. The dynamics of COVID-19 curve for Maharashtra are shown in Fig. 2(a). As per the optimistic scenario, Maharashtra may report 263700 cumulative cases by the end of the COVID-19 life-cycle, while 362 and 181 new cases per day may be reported by the 22nd of August 2020 and $31^{\text {st }}$ of August 2020 respectively.

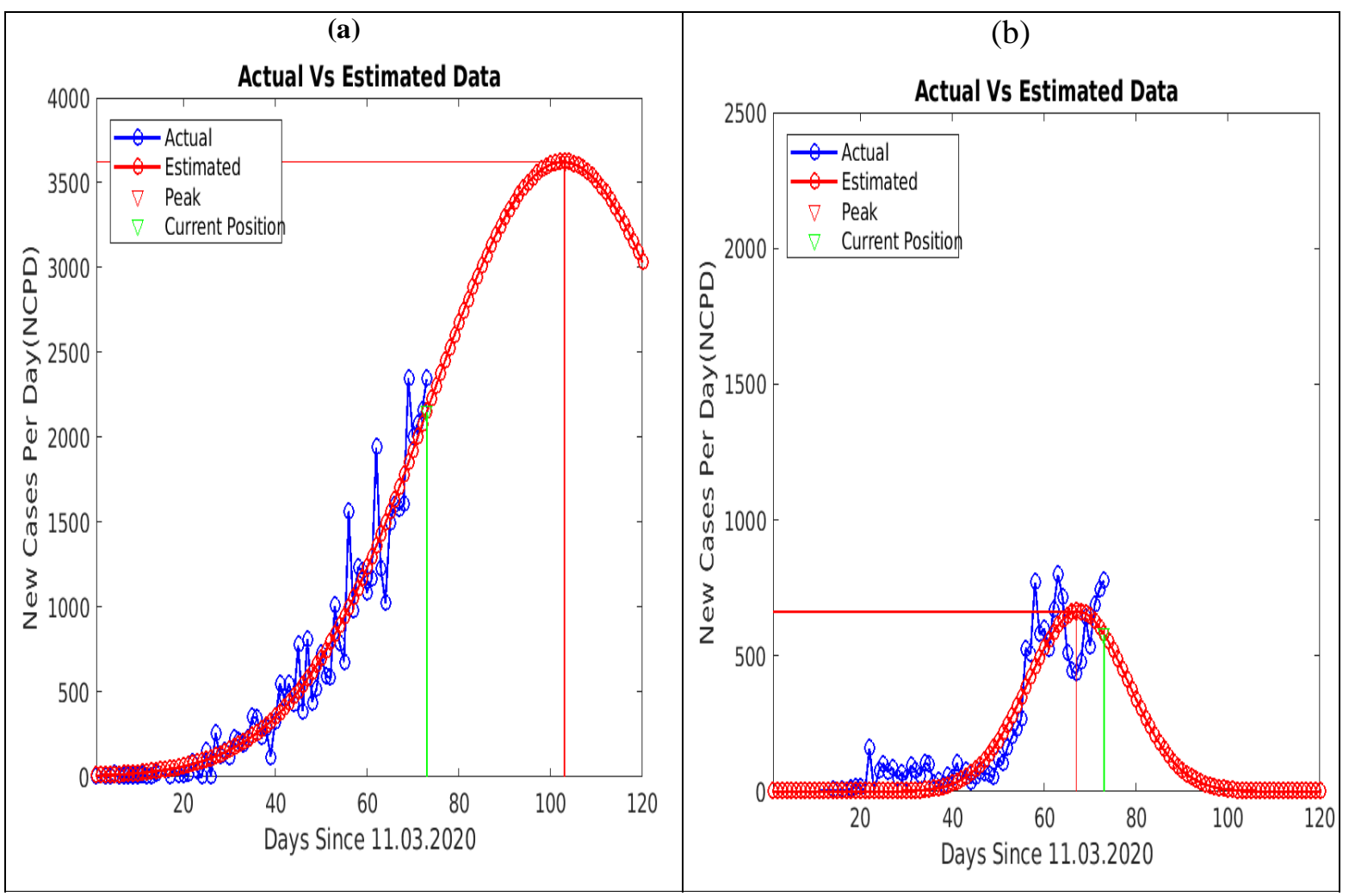

Figure.2 (a) Estimates using an optimistic scenario for Maharashtra, peak position (in red) is +30 days from the current position (in green) (b) Estimates using actual coefficients $a, b$, and $c$ for Tamil Nadu, observe that the peak position is $\mathbf{- 6}$ days from the current position.

Tamil Nadu: 776 new cases were reported in Tamil Nadu on the $22^{\text {nd }}$ of May 2020. The dynamics of the COVID-19 curve for Tamil Nadu are shown in Fig.2(b). Though Tamil Nadu reported the second-highest NCPD for India on the simulation day, yet the dynamics of the COVID-19 curve indicate flattening of the COVID-19 curve which is evident from the fact that the relative peak position is negative six days on the day of simulation. So, the Tamil Nadu Government has an opportunity to contain the outbreak by the $13^{\text {th }}$ of June 2020 with 33 new cases per day and 18140 cumulative cases by the end of COVID-19 curve. However, improper policy interventions may extend flattening of this curve with more cumulative cases. 
Delhi: 571 new cases were reported in Delhi on the $22^{\text {nd }}$ of May 2020. The dynamics of COVID-19 curve for Delhi are shown in Fig.3 (a). Simulation results suggest that, Delhi may report 50600 cumulative cases by the end of the COVID-19 life-cycle, while 66 and 33 new cases per day may be reported by the $19^{\text {th }}$ of August 2020 and $28^{\text {th }}$ of August 2020 respectively.

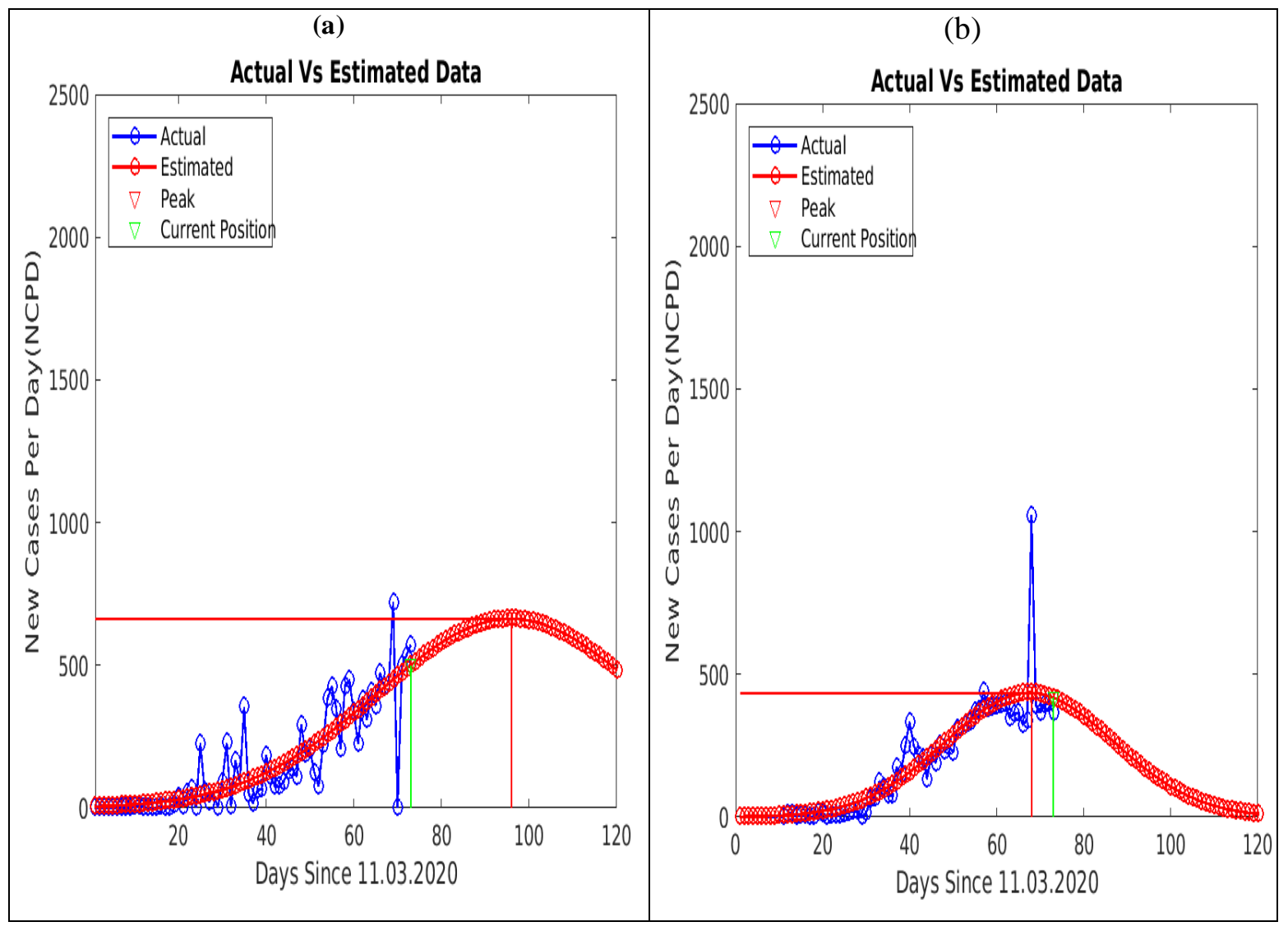

Figure.3 (a) Estimates using non-modified coefficients $a, b$, and $c$ for Delhi, peak position (in red) is less than +30 days from the current position (in green) (b) Estimates using nonmodified coefficients $a, b$, and $c$ for Gujarat, note that the peak position is - 5 days from the current position, also observe that the COVID-19 curve for Gujarat started flattening.

Gujarat: The dynamics of the COVID-19 curve for Gujarat is shown in Fig.3 (b). Gujarat reported forth highest NCPD for India on the simulation day. However, the dynamics of COVID-19 curve indicate flattening of the COVID-19 curve, which is evident from the fact that the relative peak position is negative five days on the day of simulation. So, there is an opportunity for the Gujarat Government to contain the outbreak by the $19^{\text {th }}$ of July 2020 with 33 new cases per day and 18140 cumulative cases by the end of the COVID-19 curve. However, improper policy interventions may also extend flattening of this curve with more cumulative cases. 
Uttar Pradesh: 340 new cases were reported in Uttar Pradesh on the $22^{\text {nd }}$ of May 2020. The dynamics of the COVID-19 curve for Uttar Pradesh are shown in Fig.5(a). As per the optimistic scenario, Uttar Pradesh may report 24420 cumulative cases by the end of the COVID-19 lifecycle, while 25 and 12 new cases per day may be reported by the $13^{\text {th }}$ of September 2020 and $25^{\text {th }}$ of September 2020 respectively.

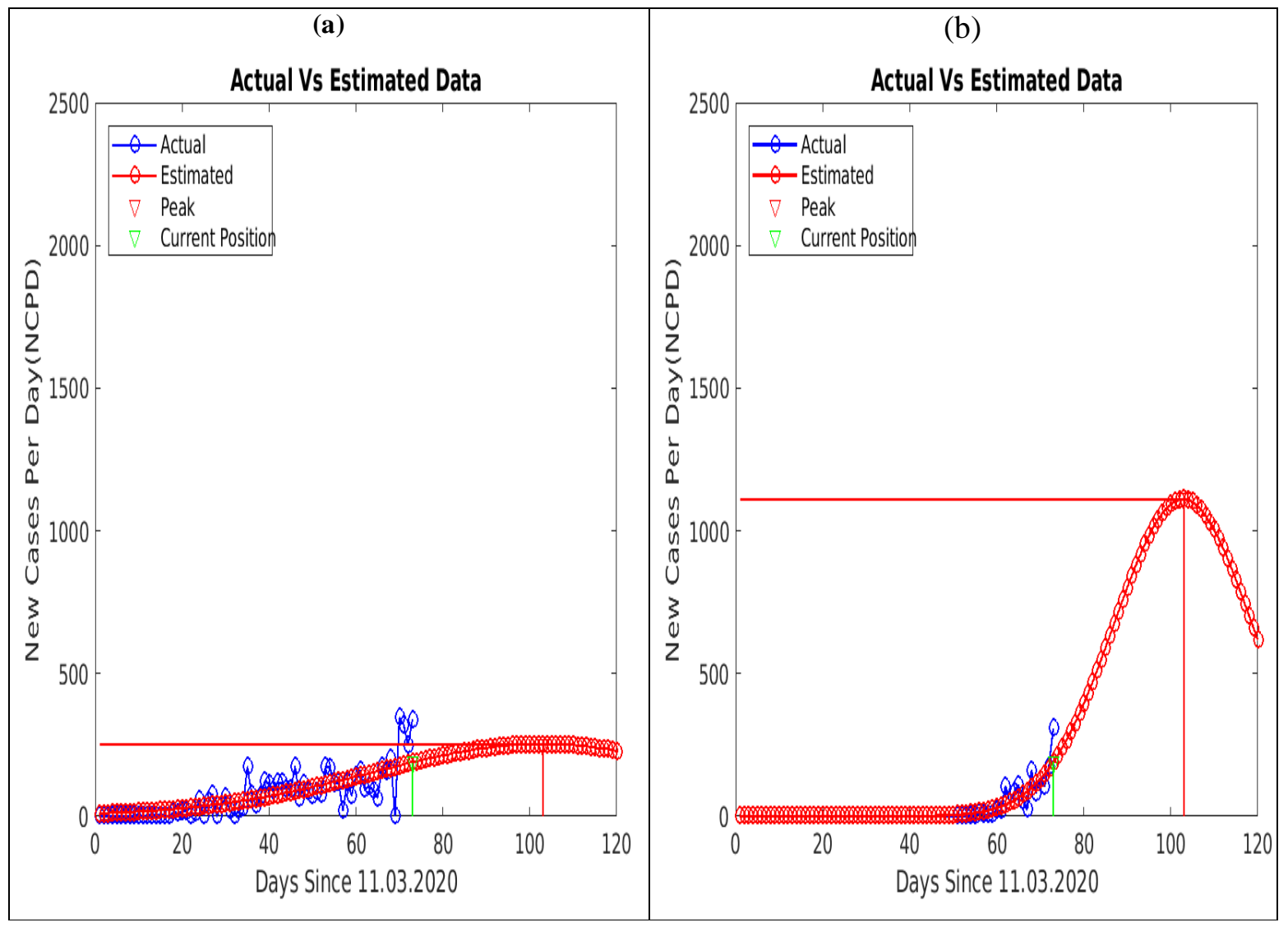

Figure.4 (a) Estimates using an optimistic scenario for Uttar Pradesh, note that position of the peak (in red) is $+\mathbf{3 0}$ days from the current position (in green) (b) Estimates using an optimistic scenario for Bihar, note the higher peak amplitude.

Bihar: 308 new cases were reported in Bihar on the $22^{\text {nd }}$ of May 2020. The dynamics of COVID-19 curve for Bihar are shown in Fig.4(b). As per the optimistic scenario, Bihar may report 44170 cumulative cases by the end of the COVID-19 life-cycle, while 111 and 55 new cases per day may be reported by the $25^{\text {th }}$ of July 2020 and $29^{\text {th }}$ of July 2020 respectively. Our simulation results suggest that the Government of Bihar has performed well during initial period of pandemic and supressed the first small wave quite efficiently. Therefore, to simulate the second major wave, we didn't consider the first small wave again. The big difference between ideal scenario and optimistic scenario is also an alarm to the Government of Bihar to lay down aggressive policy measures, to contain this outbreak 
Madhya Pradesh: 246 new cases were reported in Madhya Pradesh on the $22^{\text {nd }}$ of May 2020. The dynamics of the COVID-19 curve for Madhya Pradesh are shown in Fig.5(a). As per the optimistic scenario, Madhya Pradesh may report 27080 cumulative cases by the end of COVID-19 life-cycle, while 27 and 13 new cases per day may be reported by the $15^{\text {th }}$ of September 2020 and $26^{\text {th }}$ of September 2020 respectively.

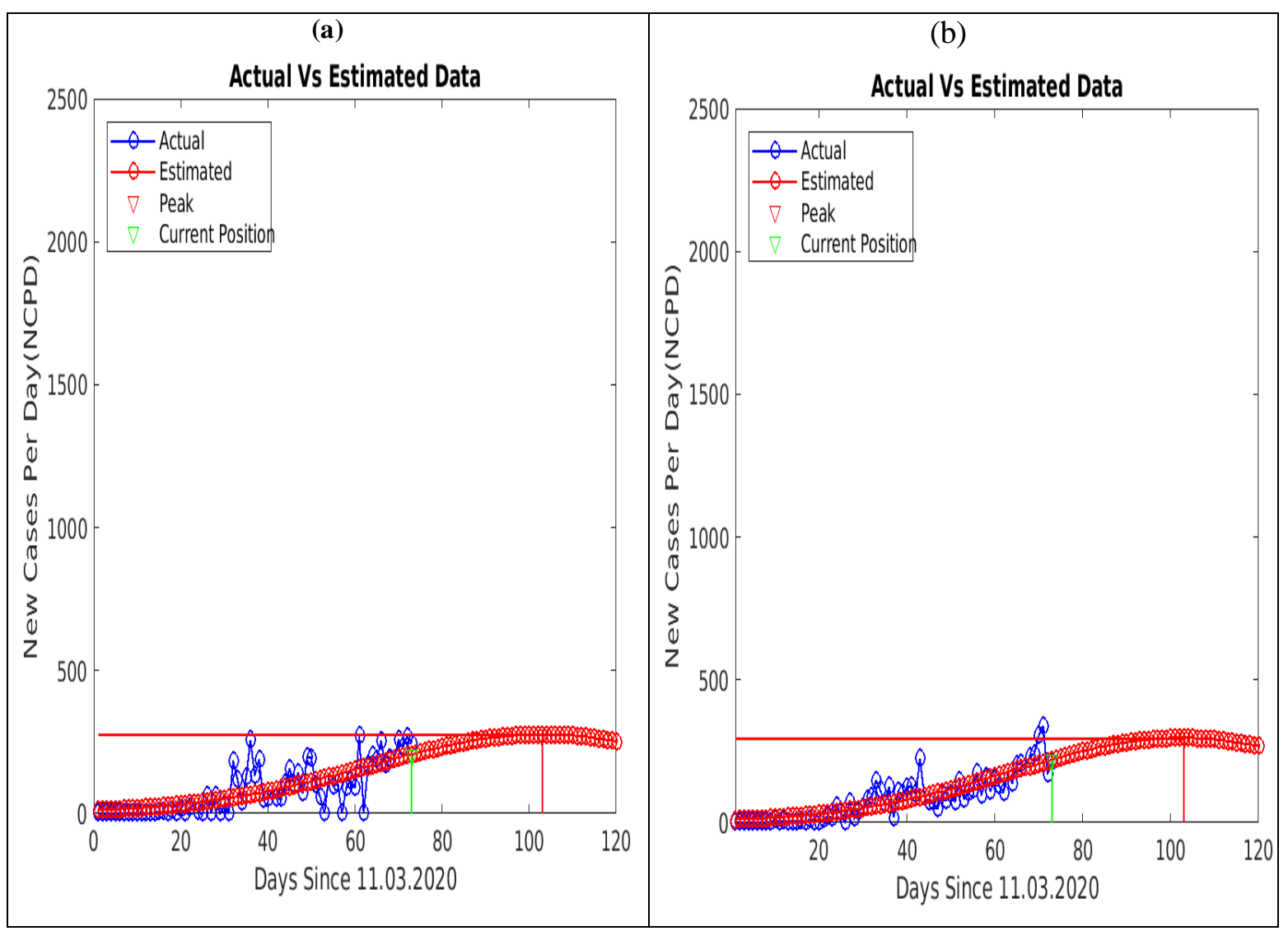

Figure.5 (a) Estimates using an optimistic scenario for Madhya Pradesh, note that the position of the peak (in red) is $+\mathbf{3 0}$ days from the current position (in green) (b) Estimates using an optimistic scenario for Rajasthan. Note the prolonged flattening of pandemic waves in both the COVID-19 curves.

Rajasthan: 212 new cases were reported in Rajasthan on the $22^{\text {nd }}$ of May 2020. The dynamics of the COVID-19 curve for Rajasthan are shown in Fig.5(b). As per the optimistic scenario, Rajasthan may report 28200 cumulative cases by the end of COVID-19 life-cycle, while 29 and 14 new cases per day may be reported by the $15^{\text {th }}$ of September 2020 and $26^{\text {th }}$ of September 2020 respectively.

The Table 2, summarises the simulation results for COVID-19 parameters such as ending lifecycles and cumulative cases for India and some of its states in different scenarios. 
Table 2: Estimates of cumulative cases and ending life-cycle for India and some of its states in different scenarios on the $22^{\text {nd }}$ of May 2020.

\begin{tabular}{|c|c|c|c|c|c|c|}
\hline Country/State & Scenario & $\begin{array}{l}\text { Cumulative } \\
\text { Cases by } \\
\text { the end of } \\
\text { the curve }\end{array}$ & $\begin{array}{r}\text { Fall of } 95 \% \\
\text { peak-ampli } \\
\text { by-2020 } \\
\text { expected cases }\end{array}$ & $\begin{array}{l}\text { f the } \\
\text { de } \\
\text { ad } \\
\text { er day }\end{array}$ & $\begin{array}{r}\text { Fall of } 90 \\
\text { peak-amr } \\
\text { by }-20 \\
\text { expected ca }\end{array}$ & $\begin{array}{l}\text { \% of the } \\
\text { itude by } \\
\text { ond } \\
\text { es per day }\end{array}$ \\
\hline India & $\begin{array}{l}\text { High } \\
\text { Optimistic } \\
\text { Ideal }\end{array}$ & $\begin{array}{l}1056000 \\
655000 \\
267200\end{array}$ & $\begin{array}{l}30^{\text {th }} \text { September } \\
8^{\text {th }} \text { September } \\
21^{\text {st }} \text { July }\end{array}$ & $\begin{array}{l}587 \\
409 \\
237\end{array}$ & $\begin{array}{l}21^{\text {st }} \text { September } \\
29^{\text {th }} \text { August } \\
15^{\text {th }} \text { July }\end{array}$ & $\begin{array}{l}1175 \\
818 \\
474\end{array}$ \\
\hline Maharashtra & $\begin{array}{l}\text { Optimistic } \\
\text { Ideal }\end{array}$ & $\begin{array}{l}263700 \\
92190\end{array}$ & $\begin{array}{l}31^{\text {st }} \text { August } \\
13^{\text {th }} \text { July }\end{array}$ & $\begin{array}{l}181 \\
94\end{array}$ & $\begin{array}{l}22^{\text {nd }} \text { August } \\
7^{\text {th }} \text { July }\end{array}$ & $\begin{array}{l}362 \\
188\end{array}$ \\
\hline Tamil Nadu & Actual/Ideal & 18140 & $13^{\text {th }}$ June & 33 & $9^{\text {th }}$ June & 66 \\
\hline Delhi & $\begin{array}{l}\text { Actual } \\
\text { Ideal }\end{array}$ & $\begin{array}{l}50600 \\
23970\end{array}$ & $\begin{array}{l}28^{\text {th }} \text { August } \\
19^{\text {th }} \text { July }\end{array}$ & $\begin{array}{l}33 \\
21\end{array}$ & $\begin{array}{l}19^{\text {th }} \text { August } \\
12^{\text {th }} \text { July }\end{array}$ & $\begin{array}{l}66 \\
42\end{array}$ \\
\hline Gujarat & Actual/Ideal & 21130 & $3^{\text {rd }}$ July & 22 & $28^{\text {th }}$ June & 44 \\
\hline Uttar Pradesh & $\begin{array}{l}\text { Optimistic } \\
\text { Ideal }\end{array}$ & $\begin{array}{l}24420 \\
13110\end{array}$ & $\begin{array}{l}25^{\text {th }} \text { September } \\
11^{\text {th }} \text { August }\end{array}$ & $\begin{array}{l}12 \\
8\end{array}$ & $\begin{array}{l}13^{\text {th }} \text { September } \\
02^{\text {nd }} \text { August }\end{array}$ & $\begin{array}{l}25 \\
17\end{array}$ \\
\hline Bihar & $\begin{array}{l}\text { Optimistic } \\
\text { Ideal }\end{array}$ & $\begin{array}{l}44170 \\
3060\end{array}$ & $\begin{array}{l}29^{\text {th }} \text { July } \\
12^{\text {th }} \text { June }\end{array}$ & $\begin{array}{l}55 \\
8\end{array}$ & $\begin{array}{l}25^{\text {th }} \text { July } \\
10^{\text {th }} \text { June }\end{array}$ & $\begin{array}{l}111 \\
16\end{array}$ \\
\hline $\begin{array}{l}\text { Madhya } \\
\text { Pradesh }\end{array}$ & $\begin{array}{l}\text { Optimistic } \\
\text { Ideal }\end{array}$ & $\begin{array}{l}27080 \\
13930\end{array}$ & $\begin{array}{l}26^{\text {th }} \text { Sept. } \\
09^{\text {th }} \text { August }\end{array}$ & $\begin{array}{l}13 \\
9\end{array}$ & $\begin{array}{l}15^{\text {th }} \text { September } \\
31^{\text {st }} \text { July }\end{array}$ & $\begin{array}{l}27 \\
19\end{array}$ \\
\hline Rajasthan & $\begin{array}{l}\text { Optimistic } \\
\text { Ideal }\end{array}$ & $\begin{array}{l}28200 \\
14220\end{array}$ & $\begin{array}{l}23^{\text {rd }} \text { Sept. } \\
07^{\text {th }} \text { August }\end{array}$ & $\begin{array}{l}14 \\
10\end{array}$ & $\begin{array}{l}11^{\text {th }} \text { September } \\
29^{\text {th }} \text { July }\end{array}$ & $\begin{array}{l}29 \\
20\end{array}$ \\
\hline
\end{tabular}


medRxiv preprint doi: https://doi.org/10.1101/2020.05.30.20117440; this version posted June 4, 2020. The copyright holder for this preprint (which was not certified by peer review) is the author/funder, who has granted medRxiv a license to display the preprint in perpetuity. It is made available under a CC-BY-NC-ND 4.0 International license .

4. Conclusion: Overestimating the COVID-19 pandemic wave parameters such as its ending life-cycle and cumulative cases may put policy makers in a dilemma. In this paper, an optimistic scenario is simulated, wherein the dynamics of the COVID-19 curve is allowed to spread to such an extent that the projections of the COVID-19 parameters do not take excessively high values. This study, suggests that by the end of major COVID-19 wave in India, there may be 655000 cumulative cases which may not be considered too high in a population of 1.38 billion people. Maharashtra is one of the major contributing states of the Indian COVID-19 curve. Pandemic waves in Tamil Nadu and Gujarat are in the flattening phase. The state government of Bihar requires special attention to contain COVID-19 outbreak while Delhi, Utter Pradesh, Madhya Pradesh, and Rajasthan may end-up with prolonged flattening.

\section{References}

1 Li. Q. et al. Early Transmission Dynamics in Wuhan, China, of Novel Coronavirus-166 Infected Pneumonia. N Engl J Med, doi:10.1056/NEJMoa2001316 (2020)

2 N. M. Ferguson et al.,. Impact of non-pharmaceutical interventions (npis) to reduce covid-19 mortality and healthcare demand. London: Imperial College COVID 19 Response Team, March 16 (2020), $10.25561 / 77482$.

3 Andrea Remuzzi, Giuseppe Remuzzi. COVID-19 and Italy: what next? the Lancent 2020; https://doi.org/10.1016/S0140-6736(20)30627-9

4 https://www.who.int/emergencies/diseases/novel-coronavirus-2019

5 https://www.ecdc.europa.eu/en/covid-19-pandemic

6 https://coronavirus.jhu.edu/map.html

7 H. Hethcote, The mathematics of infectious diseases. SIAM Rev. 42, 599653(2000). doi:10.1137/S0036144500371907

8 W. O. Kermack, A. G. McKendrick, G. T. Walker, A contribution to the mathematical theory of epidemics. Proc. R. Soc. Lond. A 115, 700-721 (1927).doi:10.1098/rspa.1927.0118

9 C. Grassly, C. Fraser, Mathematical models of infectious disease transmission. Nat. Rev. Microbiol. 6, 477-487 (2008). doi:10.1038/nrmicro1845pmid:18533288

10 J. Anderson, I. Lampl, I. Reichova, M. Carandini, D. Ferster, Stimulus dependence of two-state fluctuations of membrane potential in cat visual cortex. Nat. Neurosci. 3,617621 (2000). doi:10.1038/75797pmid:10816319

11 R. Li, S. Pei, B. Chen, Y. Song, T. Zhang, W. Yang, J. Shaman, Substantial undocumented infection facilitates the rapid dissemination of novel coronavirus (SARS-CoV-2). Science 368, 489493

12 A. J. Kucharski, T. W. Russell, C. Diamond, Y. Liu, J. Edmunds, S. Funk, R. M. Eggo;Centre for Mathematical Modelling of Infectious Diseases COVID-19 Working Group Early dynamics of transmission and control of COVID-19: A mathematical modelling study. Lancet Infect. Dis. 20, 553558 (2020). doi:10.1016/S1473-3099(20)30144-4pmid:32171059 
medRxiv preprint doi: https://doi.org/10.1101/2020.05.30.20117440; this version posted June 4, 2020. The copyright holder for this preprint (which was not certified by peer review) is the author/funder, who has granted medRxiv a license to display the preprint in perpetuity.

It is made available under a CC-BY-NC-ND 4.0 International license .

13 J. Lourenco, R. Paton, M. Ghafari, M. Kraemer, C. Thompson, P. Simmonds, P. Klenerman, S. Gupta, Fundamental principles of epidemic spread highlight the immediate need for large-scale serological surveys to assess the stage of the SARS-CoV-2 epidemic. medRxiv 2020.03.24.20042291 [Preprint]. 26 March 2020;.doi:10.1101/2020.03.24.20042291

14 Anderson RM, Heesterbeek H, Klinkenberg D, Hollingsworth TD. How will country-based mitigation measures influence the course of the COVID-19 epidemic? Lancet. 2020;395(10228):931-934. doi:10.1016/S0140-6736(20)30567-5

15 Zhao S, Lin Q, Ran J, Musa SS, Yang G, Wang W, et al. Preliminary estimation of the basic reproduction number of novel coronavirus (2019-nCoV) in China, from 2019 to 2020: A data-driven analysis in the early phase of the outbreak. Int J Infect Dis. 2020.

16 Wang L, Wu JT. Characterizing the dynamics underlying global spread of epidemics. Nat Commun. 2018;9(1):218. Published 2018 Jan 15. doi:10.1038/s41467-017-02344-Z

17 Rocchi E, Peluso S, Sisti D, Carletti M. A Possible Scenario for the Covid-19 Epidemic, Based on the SI(R) Model [published online ahead of print, 2020 May 12]. SN Compr Clin Med. 2020;1-3. doi:10.1007/s42399-020-00306-Z

18 Lauer SA, Grantz KH, Bi Q, et al. The Incubation Period of Coronavirus Disease 2019 (COVID-19) From Publicly Reported Confirmed Cases: Estimation and Application. Ann Intern Med. 2020;172(9):577-582. doi:10.7326/M20-0504

19 S.Woody et al. Projections for first-wave COVID-19 deaths across the US using social-distancing measures derived from mobile phones,2020, https://www.medrxiv.org/content/10.1101/2020.04.16.20068163v2

20 P. Gupta, K.K. Sharma, S.D. Joshi, S. Goyal, A data-driven method to detect the flattening of the COVID-19 pandemic curve and estimating its ending life-cycle using only the time-series of new cases per day.,2020, https://www.medrxiv.org/content/10.1101/2020.05.15.20103374v1.article-metrics

21 https://www.labnol.org/code/covid-19-india-tracker-200325 